\title{
Meteorological Factors Affecting Airborne Conidia Concentrations and the Latent Period of Podosphaera clandestina on Sweet Cherry
}

\author{
Gary G. Grove, Associate Plant Pathologist, Washington State University Tree Fruit Research and Extension Cen- \\ ter, Wenatchee 98801
}

\begin{abstract}
Grove, G. G. 1998. Meteorological factors affecting airborne conidia concentrations and the latent period of Podosphaera clandestina on sweet cherry. Plant Dis. 82:741-746.

Conidia of Podosphaera clandestina were trapped beginning about 1 month after bud burst and continuing through the majority of the fruit development period and beyond. The presence of airborne conidia generally followed a diurnal pattern, with peak concentrations occurring in late morning to early afternoon. The three general spore dispersal patterns described by Sutton and Jones for P. leucotricha were observed: diurnal dispersal with concentrations peaking about midday (type I dispersal); random dispersal in which the spore concentrations were not correlated with any measured meteorological parameter (type II dispersal); and dispersal associated with the onset of rain (type III dispersal). Positive correlations with wind speed and temperature, and negative correlations with relative humidity, were characteristic of days when spore dispersal was diurnal. Consistent correlations with meteorological parameters were not detected on days with random or rain-onset dispersal. The latent period of P. clandestina on cherry foliage was found to be shortest at 20 to $25^{\circ} \mathrm{C}$ and was influenced by temperature and incubation time.
\end{abstract}

Additional keywords: airborne spore concentrations, powdery mildew, Prunus avium

Powdery mildew of cherry (Prunus avium L.), caused by Podosphaera clandestina (Wallr.:Fr.) Lev., is the most serious preharvest disease of cherry in Washington State (13-15). Mildew is common on foliage and can become economically devastating if fruit infection occurs. Fruit infection usually occurs under conditions of moderate temperature and high humidity and has been observed only in orchards with high incidence and severity of foliar mildew prior to the occurrence of those conditions (15). This occurs presumably because the inoculum for fruit infection is produced on leaves (14). P. clandestina survives as cleistothecia on the orchard floor, tree crotches, and bark crevices (14). Rains or sprinkler irrigation during April and early to mid-May promote ascospore release and primary infection $(13,14)$. Mildew colonies originating from these ascosporic infections are usually few in number, inconspicuous, and generally appear in the orchard during late April to mid-May

Corresponding author: Gary G. Grove E-mail: grove@wsu.edu

Plant Pathology New Series 0230, Project 0795, College of Agriculture and Home Economics, Research and Extension Center, Washington State University, Pullman 99164-6430.

Accepted for publication 24 February 1998.

Publication no. D-1998-0506-01R

(C) 1998 The American Phytopathological Society
(14). Secondary infections of foliage continue over the next 6 to 8 weeks preceding harvest and beyond. The initial rapid increase and subsequent intensifications in the severity of powdery mildew generally occur when warm, humid weather occurs after primary mildew colonies are already established in the orchard (15). In past studies, these explosive increases in mildew severity have occurred when overwintered cleistothecia are no longer viable, after primary mildew colonies have been observed, and after conidia of the pathogen have been detected in the orchard air (1315). Because ascospore-derived colonies provide the initial dose of secondary inoculum, their number can reportedly have a profound influence upon the severity of grape powdery mildew (11). Therefore corresponding levels of ascosporic infection by $P$. clandestina could perhaps affect the progress of a cherry mildew epidemic in a similar fashion. It is the conidial stage that is responsible for rapid increases in the mildew severity on cherry leaves and fruit once the potential for primary infection has passed. Foliar mildew continues to be severe after harvest, partly because Washington growers halt fungicide applications at harvest. It is unclear to what extent increases in postharvest mildew incidence and severity affect the epidemiology of the disease during subsequent years.

Numerous reports document the effect of meteorological parameters on dispersal of powdery mildew ascospores and conidia (1-3,18-20,23-27,28,31-33,35,37,40-42).
Sutton and Jones (35) documented three types of conidia dispersal for Podosphaera leucotricha: type I dispersal is characterized by diurnal periodicity and is correlated with certain meteorological parameters; type II dispersal is not correlated with any measured meteorological parameters; and type III dispersal is associated with rain. Factors affecting concentrations of $P$. clandestina conidia in the air in proximity to hawthorn (Crataegus monogyna L.) have been reported (18). However, there is no information on factors affecting aerial spore concentrations or dispersal of $P$. clandestina conidia in sweet cherry orchards in eastern Washington.

The powdery mildews of grape and cherry are epidemiologically similar $(10,11,13-15,26)$. Similarities include the presence of a functional ascigerous state $(14,26)$, epidemiological similarities in the response of the sexual stage to moisture (13), and the influence of temperature and moisture stress on germination of conidia $(10,15)$. Several systems or criteria have been described for forecasting powdery mildew of grape: those developed in New York and California have accurately identified primary infection periods or measured disease pressure in their respective geographical areas $(11,36,39)$. Those criteria or models are based upon the factors affecting ascospore release and primary infection (11) or on the factors affecting ascospore release, primary infection, and disease pressure during the repeating cycle (36). Similar approaches may prove useful for the management of cherry powdery mildew. The meteorological factors affecting the release and germination of ascospores (13) and meteorological and host factors affecting germination of conidia on fruit and foliage (15) have been described. Germination of conidia was shown to be promoted by low vapor pressure deficits and temperatures of 15 to $25^{\circ} \mathrm{C}(15)$. However, there is no information on the effect of these variables on the latent period (i.e., the elapsed time between the onset of the infection process and the beginning of production of the subsequent spore crop) of conidial infections under similar conditions. Such information could provide a method for measuring disease pressure and could be a critical component in the development of a forecasting system for management of cherry powdery mildew.

The purposes of this study were to determine the effect of meteorological condi- 
tions on airborne concentrations of $P$. clandestina conidia and to develop preliminary information on the effects of temperature and vapor pressure deficit on the latent period of the disease.

\section{MATERIALS AND METHODS}

Orchard spore trapping. Conidia trapping studies were conducted during the 1989 and 1990 growing seasons in an 11.2ha commercial sweet cherry (cv. Bing) orchard comprised of 40-year-old trees located near Malaga, Washington. During the second year, studies were also conducted in a 3.2-ha commercial orchard near Orondo, Washington. Each spring, a Burkhard volumetric spore trap (Burkhard Mfg. Co., Rickmansworth, Hertfordshire, Eng.) was placed in each orchard prior to bud break and adjusted to sample $10 \mathrm{~L}$ of air per min. Traps were positioned so that the sampling orifices were about $0.5 \mathrm{~m}$ above the ground. Impaction tapes were coated with a thin layer of silicon grease prior to placement in the trap. Tapes were retrieved at 7-day intervals, cut into 48-mm segments corresponding to $24-\mathrm{h}$ periods (0000 to $2300 \mathrm{~h}$ ), and mounted in several drops of lactophenol on glass slides. Tapes were examined at 2-mm intervals in traverses perpendicular to the directions of movement. Counts were corrected to compensate for the area sampled and recorded as the number of conidia per cubic meter of air sampled per hour. Dataloggers (CR21X, Campbell Scientific, Logan, UT)

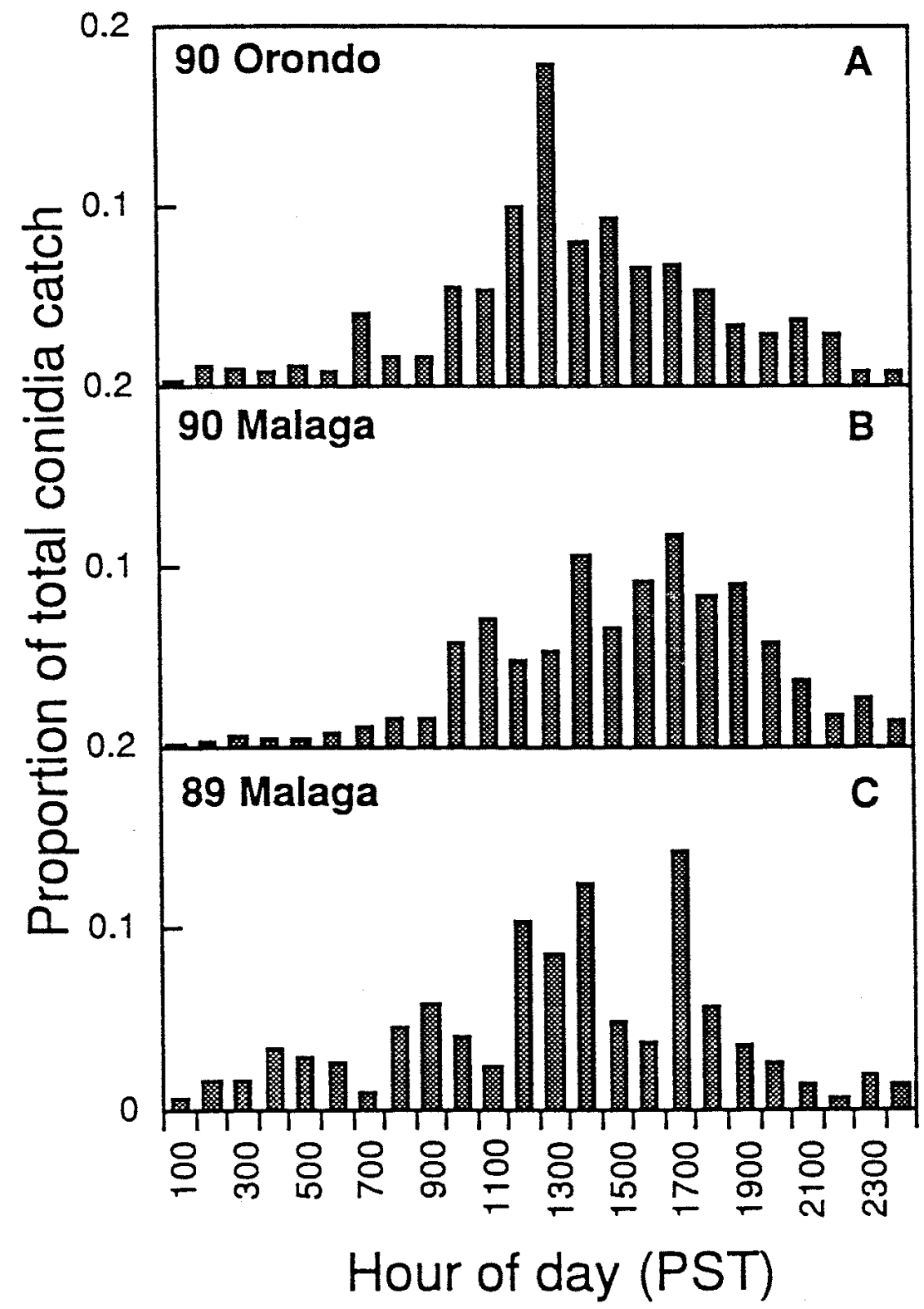

Fig. 1. Diurnal periodicity of Podosphaera clandestina conidia trapped from the air of sweet cherry orchards in Malaga (A,B) and Orondo (C), Washington, during spring and summer of 1989 and 1990. Values given are the proportion of the total seasonal spore catch that were trapped during each hour from 0000 to $2300 \mathrm{~h}$ Pacific Standard Time. Values were obtained from 130, 150, and 180 days of air sampling at Malaga-1989, Malaga-1990, and Orondo-1990, respectively. Conidia were trapped by a Burkhard volumetric spore trap operated continuously. located $2 \mathrm{~m}$ from the traps provided hourly measurements of temperature, relative humidity, leaf wetness, and wind speed. Temperature (Model 107, Campbell Scientific), relative humidity (Phys-Chem Sensors, Phys-Chem Inc., New York, NY), leaf wetness (Model 237, Campbell Scientific), wind speed (R.M. Young Model 03001-5, R.M. Young Co., Traverse City, MI), and direction sensors (R.M. Young Model 03001-5) connected to the dataloggers provided hourly measurements of these meteorological parameters. Sensors were positioned near tree crotches about $1.0 \mathrm{~m}$ above the orchard floor. The time, amount, and duration of rainfall were obtained from a National Weather Service office in Wenatchee, Washington, 5 and 10 $\mathrm{km}$ from the Malaga and Orondo sites, respectively.

In 1989, sulfur was applied for mildew control at $3.7 \mathrm{~kg} / \mathrm{ha}$ on days 110 and 129 , and fenarimol was applied at 0.19 liter/ha on day 152. In 1990 at the Malaga site, fenarimol was applied at 0.19 liter/ha on days 124, 139, and 150. At the Orondo site, sulfur was applied at $3.7 \mathrm{~kg} / \mathrm{ha}$ on day 127, and fenarimol was applied at 0.19 liter/ha on days 151 and 165 .

Latent period studies. Inoculum production and harvest. Because numerous attempts to maintain clonal isolates of $P$. clandestina have been unsuccessful, conidia derived from a composite of isolates (15) were used for all latent period studies. The collection of isolates, production of healthy leaf tissue for inoculation, and inoculum production and harvest have been described previously (15).

All inoculations were performed with conidia from colonies 7 to 8 days old. Detached leaf culture $(10,15,40)$ was used to determine the effects of temperature, incubation period, and vapor pressure deficit on the latent period of $P$. clandestina on cherry leaves. Leaves were inoculated using a camel-hair brush by transferring freshly harvested conidia onto abaxial leaf surfaces of 14-day-old healthy cherry leaves. Conidia were brushed over leaf surfaces as uniformly as possible. Inoculated leaves were placed on metal screens about $2 \mathrm{~cm}$ above the surface of anhydrous glycerol:water solutions mixed in proportions calculated to result in relative humidities of $95,97.5$, and $100 \%(4,5,15$, 17). Leaves were incubated 2,4 , or 6 days at $10,15,20,25$, and $30^{\circ} \mathrm{C}$ in a previously described temperature-humidity control unit $(15,28,30,34)$. Temperature, relative humidity, and leaf wetness within each chamber were continuously monitored using a previously described sensing and data recording apparatus (15). The humidities tested corresponded to vapor pressure deficits of 0 to $0.64,0$ to $0.87,0$ to 1.2 , and 0 to $1.6 \mathrm{~Pa}$, respectively. The experiment was designed as a three-factor experiment (temperature, vapor pressure deficit, and incubation period) with four observations 
in each treatment. At the conclusion of respective incubation periods, epidermal peels were made $(10,15,40)$, mounted on glass slides in lactophenol, and observed microscopically at $\times 100$ for the presence of conidia. The proportion of leaves with sporulating colonies was recorded. Four leaves were tested at each combination of temperature, incubation time, and vapor pressure deficit. The experiment was conducted twice.

Data analyses. Conidia trapping studies. Statistical analyses were conducted using Minitab Data Analysis Software (Minitab Inc., State College, PA). Analyses were conducted on hourly data for each day from harvest until the conclusion of the air-sampling experiments. Preharvest data were not included in the analyses because fungicide applications were made through most of the fruit development period. Fungicide applications were halted 2 weeks prior to harvest. Correlation analysis was used to determine the relationship of temperature $(T)$, relative humidity $(R H)$, wind speed $(W)$, and leaf wetness $(L W)$ on the number of conidia trapped per hour within each 24 -h period (i.e., each day of the study) corresponding to 0000 to $2300 \mathrm{~h}$. Conidia numbers were transformed by $\log _{10}$ (number of conidia trapped per hour +1 ) to stabilize variances.

Regression analysis was used to investigate the effect of two-factor interactions between meteorological variables on hourly spore concentrations (35). The logarithm (base 10) of hourly spore counts $(+1)$ for each 24-h period was regressed on $T, T$ $\times R H, T \times W, T \times L W, R H \times W, R H \times L W$, and $W \times L W$.

Latent period studies. Relative humidity values from each chamber were converted to vapor pressure deficit $(V)$ according to published formulae given by other workers $(31,32,38)$. Data on $Y$ (proportion of leaves with sporulating colonies) was transformed using the arcsine transformation (22). Regression analysis (22) was used to describe the effect of temperature, vapor pressure deficit, and incubation period $(I)$ on the latent period $(Y)$ of $P$. clandestina. All possible combinations of $T, T^{2}, T^{3}, T \times V \times$
$I, T \times I, I \times V, T^{2} \times V, T^{2} \times I, T^{3} \times V, T^{3} \times I$, $T^{2} \times V \times I$, and $T^{3} \times V \times I$ were evaluated for significance of regression coefficients, coefficients of determination $\left(R^{2}\right)$, coefficients of determination adjusted for degrees of freedom $\left(R_{a}^{2}\right)$, and pattern and distribution of residuals (22). Each analysis was done on the two trials separately, and then on the pooled data. An $F$ test was conducted to determine if combining the data from both experiments was warranted (21).

\section{RESULTS}

Orchard spore trapping. In general, the concentration of powdery mildew conidia in the orchard air followed a diurnal pattern (Fig. 1). The hour(s) of peak concentration varied slightly by orchard and by year. In 1989, 17 ascospores were trapped on day 117 when $1.2 \mathrm{~cm}$ of precipitation occurred; conidia were first trapped from mid-May (day of year 129) until the termination of the experiment in September (Fig. 2). Values ranged from 1 conidium per day early in May to $>4,000$

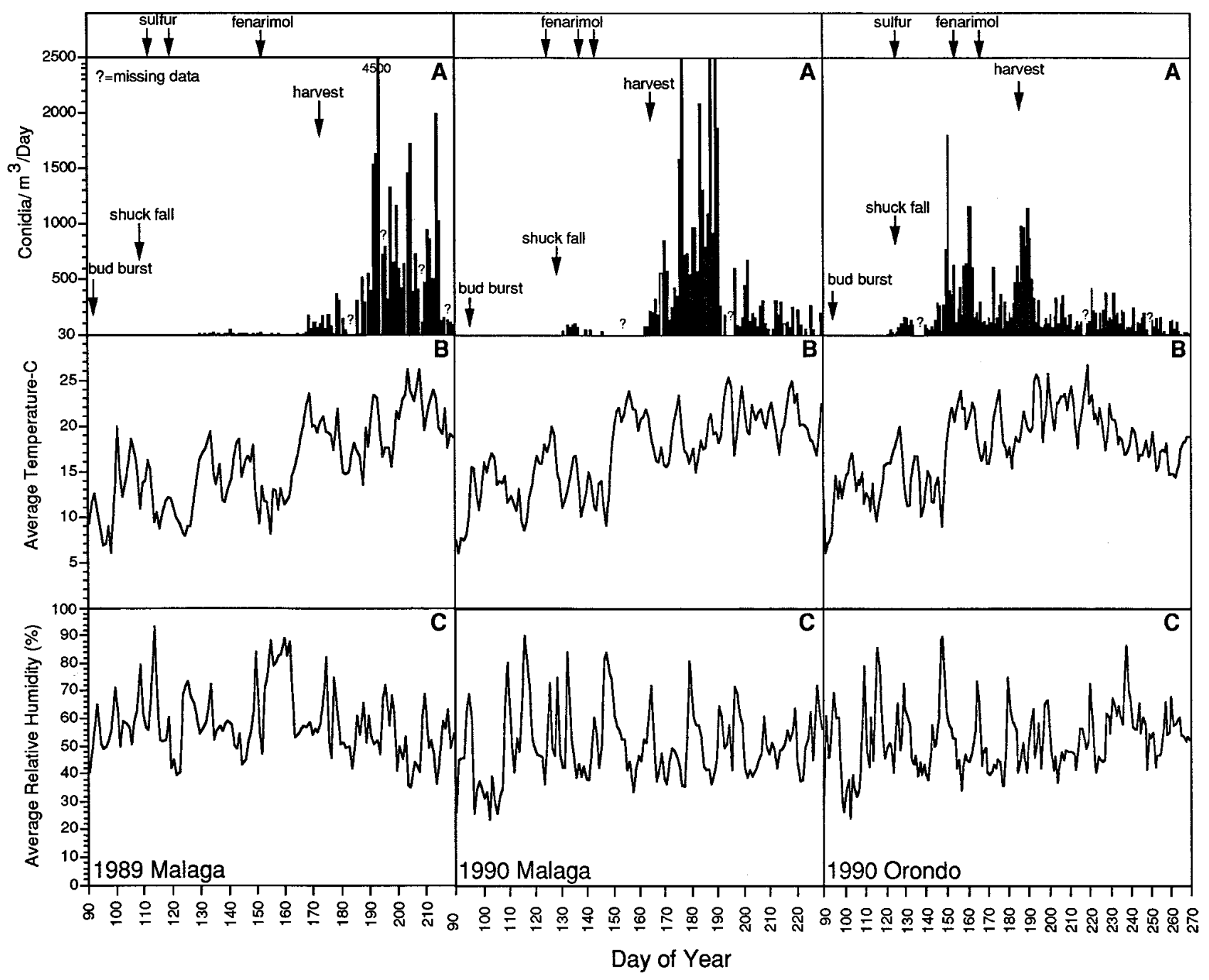

Fig. 2. Daily totals of airborne Podosphaera clandestina conidia (A), average daily temperature (B), and average daily relative humidity (C) in sweet cherry orchards in Malaga and Orondo, Washington, during spring and summer of 1989 and 1990. Conidia were trapped by a Burkhard volumetric spore trap operated continuously. Missing data indicate days when no data were collected due to spore trap failure. 
conidia per day, with concentrations peaking in early July, immediately after harvest. Counts then gradually declined. Spore counts were not recorded on days 182, 183, 223 to 228 , and 231 to 235 due to spore trap failure. In 1990 at the Malaga site (Fig. 2), 23 ascospores were trapped during a rain event on day 114 , when $1 \mathrm{~cm}$ of precipitation occurred; conidia were trapped from early May (day 122) until the termination of the experiment on day 230. Daily spore catches increased throughout May and June, peaking at 4,276 on 7 July (day 188), about 2 weeks after harvest. Concentrations then declined gradually. Spore counts were not recorded on days 139 to $141,162,194$ to 196 , and 237 to 241 due to spore trap failure. At the Orondo site in 1990 (Fig. 2), nine ascospores were trapped during a rain event on day 114 , when $1 \mathrm{~cm}$ of precipitation occurred; conidia were trapped beginning in early May (day 122) and continued until the termination of the experiment on day 270. Daily spore catches increased throughout May and peaked at 1,800 conidia on day 151 (31 May), about 3 weeks prior to harvest. After harvest, values peaked again at 1,146 conidia on day 190 . Spore counts were not taken on days 135 to $139,217,218,249$, and 250 due to spore trap failure.

On the majority of days, the logarithm of hourly spore concentrations was positively correlated with temperature and wind speed and negatively correlated with relative humidity (Table 1 ). The magnitude of $r$ was variable. Consistent correlations with leaf wetness were not observed. No consistent or definitive two-factor interactions were detected by regression analyses.

Visual inspection of daily plots of spore concentrations versus meteorological factors, and correlation analysis of daily data, revealed three general patterns of spore dispersal (Fig. 3), as previously described by Sutton and Jones (35). Dispersal was generally diurnal, with spore concentrations peaking late morning to afternoon (Fig. 3A). Correlations of spore counts were generally positive with temperature and wind speed and negative with relative humidity. Type I dispersal was recorded on $85.3 \%$ of days. Rain onset (type III) dispersal (Fig. 3B) was recorded on $4.2 \%$ of days. Consistent correlations between spore counts and meteorological parameters were not observed on days with type III dispersal. Counts generally increased with the onset of rain and then decreased as the duration of leaf wetness increased. Dispersal not associated with any measured meteorological parameter (Fig. 3C; type II or random dispersal) occurred on $10.5 \%$ of days. Spore counts were generally lower on days characterized by this type of dispersal. There were no apparent seasonal patterns in frequency of occurrence of the three respective dispersal types during the season.

Latent period studies. Conidia were not produced at 10 or $30^{\circ} \mathrm{C}$. At $95,97.5$, and $100 \%$ relative humidity, sporulation required 4 to 6 days at 15 to $25^{\circ} \mathrm{C}$ (Table $2)$. The data from the two experiments were not significantly different $(F=0.17)$. The equation from the combined data is $Y$ $=0.4+0.28 I+-0.0027 T^{2} I+(-0.0001) T^{3} I$ where $Y=\sqrt{\text { arcsine }}$ proportion of leaves with sporulating colonies, $T=$ temperature, and $I=$ days of incubation best described the latent period with $R^{2}=0.70\left(R_{a}^{2}=\right.$ 0.69 ), and $s=0.30$. Estimated parameters were significant at $P=0.05$. Residuals had a random pattern and were normally distributed.

\section{DISCUSSION}

Conidia were present in the orchard air through the majority of the fruit development period. During 1989, at least 2 weeks elapsed between the time of initial exposure of fruit surfaces to the orchard air and the initial detection of airborne inoculum. In 1990, conidia were present in the air of the Orondo orchard throughout the fruit development period. Previous studies (15) have indicated that fruit susceptibility may be highest when fruit is immature, i.e., when soluble solids are lower than about 14 to $16 \%$. Therefore, the protracted coincidence of inoculum availability and fruit susceptibility indicates that the potential for fruit infection exists whenever soluble solids are below these levels. During both years of the study, this window of fruit susceptibility consisted of a 6- to 7-week period. The length of time that fruit are exposed to airborne inoculum would depend in large part upon the time of primary infection. Until a suitable weather-driven approach to fungicide application is implemented, immature fruit should be protected with fungicides whenever secondary inoculum is present in the orchard air.

Several patterns of spore dispersal have been reported previously for apple powdery mildew (35). As reported for P. leucotricha and for other powdery mildews, the predominant patterns of airborne conidia concentrations of $P$. clandestina followed a diurnal pattern, where peak concentrations of conidia were recorded in late morning or early afternoon $(7,8,12,18$ 20,23-25,27,31,32,35,37,41,42). Airborne concentrations were positively correlated with temperature and wind speed, and negatively correlated with relative humidity. This type of dispersal occurs during the sunny, dry, and relatively windy days that predominate in eastern Washington during late spring and summer. Results are similar to those reported for the distribution of conidia in the vicinity of infected hawthorn (18) trees, where most propagules were

Table 2. Influence of incubation time and temperature at $95,97.5$, and $100 \%$ relative humidity on the latent period of Podosphaera clandestina on leaves ${ }^{\mathrm{a}}$ of sweet cherry

\begin{tabular}{cccc}
\hline & \multicolumn{3}{c}{ Incubation time (days) under relative humidity (\%) } \\
\cline { 2 - 4 } Temperature $\left({ }^{\circ} \mathbf{C}\right)$ & $\mathbf{9 5}$ & $\mathbf{9 7 . 5}$ & $\mathbf{1 0 0}$ \\
\hline 10 & - & - & - \\
15 & 6 & 6 & 6 \\
20 & 4 & 4 & 4 \\
25 & 6 & 4 & 4 \\
30 & - & - & - \\
\hline
\end{tabular}

${ }^{a}$ Inoculated leaves were incubated for various time periods at different temperatures and relative humidities. Numbers in columns are the number of days required for sporulation at the indicated temperatures and relative humidities. Dashes indicate conditions under which no sporulation occurred.

Table 1. Coefficients of correlation between the $\log _{10}$ Podosphaera clandestina conidia concentrations ${ }^{\mathrm{a}}$ and meteorological factors in 1989 and 1990 in Orondo and Malaga, Washington ${ }^{\mathrm{b}}$, sweet cherry orchards

\begin{tabular}{|c|c|c|c|c|c|c|c|c|c|}
\hline \multirow[b]{2}{*}{ Location } & \multicolumn{3}{|c|}{ Temperature } & \multicolumn{3}{|c|}{ Relative humidity } & \multicolumn{3}{|c|}{ Wind } \\
\hline & Positive $^{c}$ & Negative $^{d}$ & Range & Positive & Negative & Range & Positive & Negative & Range \\
\hline 1989 Malaga & 72.3 & 8.5 & -0.24 to 0.85 & 27.7 & 61.7 & -0.85 to 0.75 & 81.7 & 21.3 & -0.54 to 0.70 \\
\hline 1990 Malaga & 92.6 & 1.9 & -0.22 to 0.86 & 13.0 & 72.2 & -0.87 to 0.59 & 40.7 & 27.7 & -0.48 to 0.49 \\
\hline 1990 Orondo & 91 & 7.1 & -0.38 to 0.82 & 16.1 & 73.2 & -0.84 to 0.61 & 75.0 & 10.7 & -0.37 to 0.88 \\
\hline
\end{tabular}

${ }^{a}$ Concentrations were transformed to $\log 10+1$.

${ }^{\mathrm{b}}$ Conidia were trapped using a Burkhard volumetric spore trap operated continuously. Analyses were conducted on 40, 60, and 90 days of spore trapping data from Malaga 1989, Malaga 1990, and Orondo 1990, respectively.

${ }^{\mathrm{c}}$ Percentage of days that $r$ was a significant positive correlation.

${ }^{\mathrm{d}}$ Percentage of days that $r$ was a significant negative correlation. 
trapped during late morning or early afternoon. However, our results differ from the findings of Khairi and Preece (18) because $P$. clandestina conidia were also detected in sweet cherry orchards in early to late evening. However, there were days when spore concentrations were not correlated with any of these meteorological parameters. There was no apparent pattern to the occurrence of days with this type of airborne conidia concentrations. Similar results have been reported for the effects of these parameters on the dispersal of conidia of Podosphaera leucotricha (35).

A less common event, the increased conidia concentrations following the onset of rain, may be a critical component in the epidemiology of the disease. Germination of $P$. clandestina conidia and infection is promoted by high humidity (15). The spore clouds present immediately after the onset of rain probably occur in response to the physical impaction of raindrops on mildew colonies (16). Therefore, spore clouds are produced immediately prior to and (in the case of intermittent showers common during this time of year in eastern Washington) during periods of increasing humidity. Rain events during fruit development may serve the dual epidemiological purposes of providing a spore dispersal mechanism and conducive meteorological conditions for the germination of these propagules and subsequent establishment of the fungus on foliage and fruit. Disease severity is notably higher during years with above-average late-spring and early-summer precipitation (13-15).

The latent period of the disease was found to be exceedingly short and is similar to the incubation period reported for Uncinula necator (6). Longer latent periods have been reported for Erysiphe graminis (29). Temperature and vapor pressure deficit had significant and insignificant effects, respectively, on the length of the latent period in our studies. However, a very limited range of moisture stress ( $\mathrm{Pa}$ corresponding to 95 to $100 \%$ $\mathrm{RH})$ was tested in our experiments. Perhaps higher levels of moisture stress would

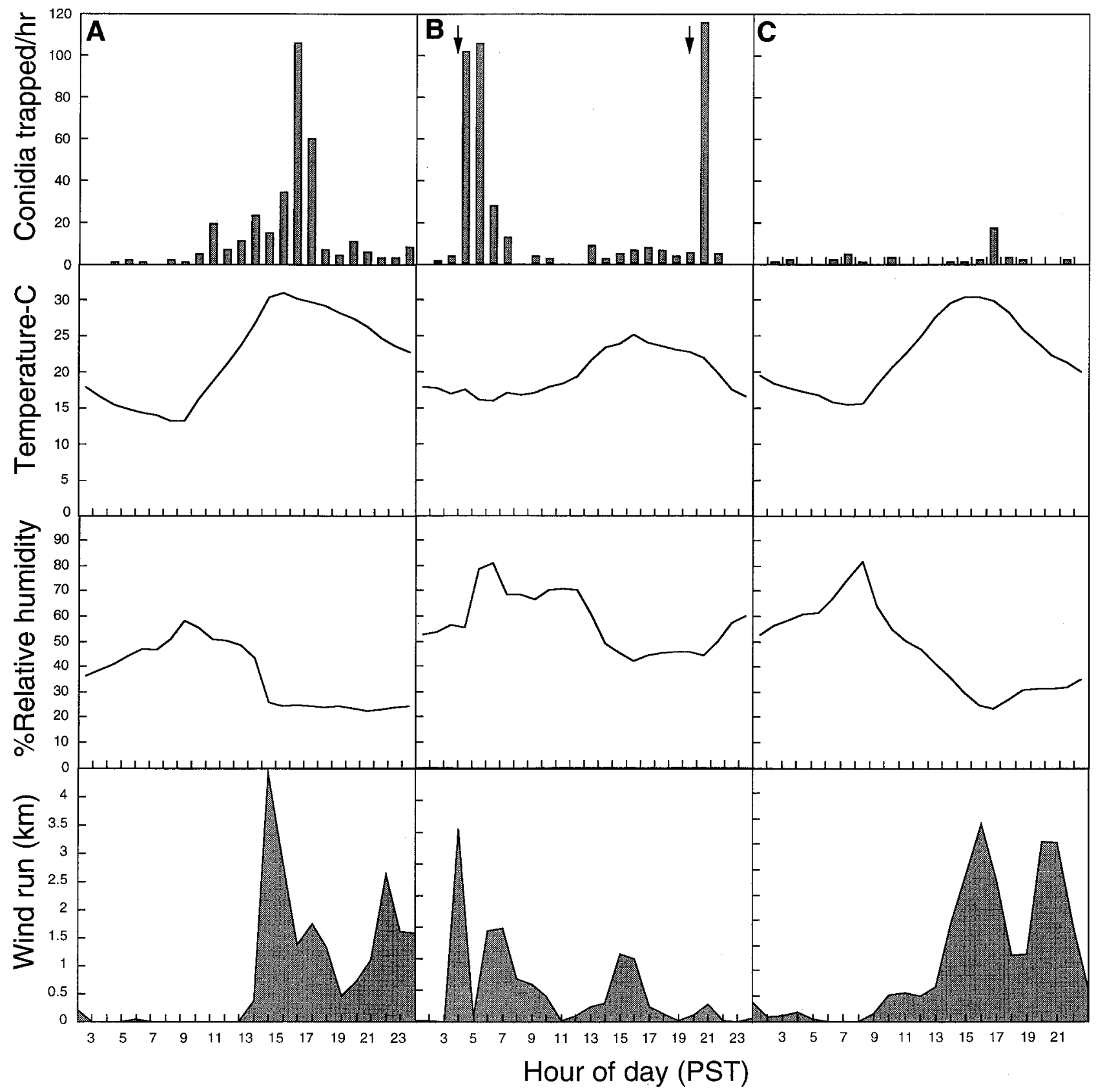

Fig. 3. Representative days when normal (A), rain-onset (B), or random (C) dispersal of conidia of Podosphaera clandestina occurred in a sweet cherry orchard in Orondo, Washington, during spring and summer of 1990. Conidia were trapped by a Burkhard volumetric spore trap operated continuously. Arrows indicate onset of rain. 
have a more significant influence on the latent period of the disease. Our results indicate that once a conidium of $P$. clandestina reaches a suitable infection court, sporulation can occur within 4 to 5 days under conducive meteorological conditions. The short latent period described here for $P$. clandestina may partially account for rapid increases in mildew severity following warm, moist weather when mildew is already established in the orchard.

\section{ACKNOWLEDGMENTS}

I gratefully acknowledge the support of this project by the Washington State Tree Fruit Research Commission, Oregon Cherry Commission, and the Agricultural Research Center, Washington State University, Pullman. I thank Nancy B. Roberts and R. J. Boal for excellent technical assistance.

\section{LITERATURE CITED}

1. Barnes, G. 1969. A micro-ecological study of fungi on the leaves of clover. Ph.D. thesis. University of Leeds, Eng.

2. Burchhill, R. T. 1957. Observations on the mode of perennation of apple mildew. Pages 114-123 in: Annu. Rep. Long Ashton Res. Stn., University of Bristol.

3. Burchhill, R. T. 1965. Seasonal fluctuations in spore concentrations of Podosphaera leucotricha (Ell. \& Ev.) Salm. in relation to the incidence of leaf infections. Ann. Appl. Biol. 55:409-415.

4. Buxton, P. A., and Mellanby, K. 1934. The measurement and control of humidity. Bull. Entomol. Res. 25:171-175.

5. Carson, F. T. 1931. Control of relative humidity in a small enclosed space. Pap. Trade J. 93:71-74.

6. Chellemi, D. O., and Marois, J. J. 1991. Sporulation of Uncinula necator on grape leaves as influenced by temperature and cultivar. Phytopathology 81:197-201.

7. Childs, J. F. L. 1940. Diurnal cycle of spore maturation in certain powdery mildews. Phytopathology 30:65-73.

8. Cimanowski, J. 1969. Epidemiologia maczniaka jabloniowego Podosphaera leucotricha (Ell. et Ev.) Salm. w Polsce. Acta. Agrobot. 22:265-280.

9. Cole, J. S. 1966. Powdery mildew of tobacco (Erysiphe cichoracearum DC). IV. Conidial content of the air within infected crops. Ann. Appl. Biol. 57:445-450.
10. Delp, C. J. 1954. Effect of temperature and relative humidity on the grape powdery mildew fungus. Phytopathology 44:615-626.

11. Gadoury, D. M., Seem, R. C., Magarey, P. A., Emmett, R., and Magarey, R. Effects of environment and fungicides on epidemics of grape powdery mildew: Considerations for practical model development and disease management. Vitic. Enol. Sci. In press.

12. Gregory, P. H., and Sreeralulu, T. 1958. The air-spore of an estuary. Trans. Br. Mycol. Soc. 41:145-156.

13. Grove, G. G. 1991. Powdery mildew of sweet cherry: Influence of temperature and wetness duration on release and germination of ascospores of Podosphaera clandestina. Phytopathology 81:1271-1275.

14. Grove, G. G., and Boal, R. J. 1991. Overwinter survival of Podosphaera clandestina in eastern Washington. Phytopathology 81:385391.

15. Grove, G. G., and Boal, R. J. 1991. Factors affecting germination of conidia of Podosphaera clandestina on leaves and fruit of sweet cherry. Phytopathology 81:1513-1518.

16. Hirst, J. M., and Stedman, O. J. 1963. Dry liberation of fungus spores by raindrops. J. Gen. Microbiol. 33:335-344.

17. Johnson, C. G. 1940. The maintenance of high atmospheric humidities for entomological work with glycerol-water mixtures. Ann. Appl. Biol. 27:295-297.

18. Khairi, S. M., and Preece, T. F. 1979. Hawthorn powdery mildew: Diurnal and seasonal distribution of conidia in air near infected plants. Trans. Br. Mycol. Soc. 71(3):395-397.

19. Last, F. T. 1955. The spore content of air within and above mildew-infected cereal crops. Trans. Br. Mycol. Soc. 38:453-464.

20. Molnar, J. 1970. Vyskyt knocentracia konidii a priebeh sekundarnej infekcie mucnatky jablonovej. Orchrana Rostlin 43:207-214.

21. Neter, J., and Wasserman, W. 1974. Applied Linear Statistical Models. 1st ed. Richard D. Irwin, Homewood, IL.

22. Neter, J., Wasserman, W., and Kutner, M. H. 1985. Applied Linear Statistical Models. 2nd ed. Richard D. Irwin, Homewood, IL.

23. Pady, S. M. 1972. Spore release in powdery mildews. Phytopathology 62:1099-1100.

24. Pady, S. M., Kramer, C. L., and Clary, R. 1969. Sporulation in some aspects of Erysiphe. Phytopathology 59:844-848.

25. Pady, S. M., and Subbayya, J. 1970. Spore release in Uncinula necator. Phytopathology 60:1702-1703.

26. Pearson, R. C., and Gadoury, D. M. 1987.
Cleistothecia, the source of primary inoculum for grape powdery mildew in New York. Phytopathology 77:1509-1514.

27. Peries, T. F. 1962. Studies on strawberry mildew, caused by Sphaerotheca macularis (Wallr. ex Fries) Jaczewski. I. Biology of the fungus. Ann. Appl. Biol. 50:211-224.

28. Rogers, W. E. 1960. A microenvironment chamber for critical control of relative humidity. Phytopathology 56:980-982.

29. Rouse, D. I., Nelson, R. R., MacKenzie, D. R., and Armitage, C. R. 1980. Components of rate-reducing resistance in seedlings of four wheat cultivars and parasitic fitness in six isolates of Erysiphe graminis f. sp. tritici. Phytopathology 70:1097-1100.

30. Scharpf, R. F. 1964. A compact system for humidity control. Plant Dis. Rep. 48:66-67.

31. Schnathorst, W. C. 1959. Spread and life cycle of the lettuce powdery mildew fungus. Phytopathology 49:464-468.

32. Schnathorst, W. C. 1965. Environmental relationships in the powdery mildews. Annu. Rev. Phytopathol. 3:343-366.

33. Stavely, J. R., and Hanson, E. W. 1966. Some effects of temperature and relative humidity on development of Erysiphe polygoni on Trifolium pratense. Phytopathology 56:940-943.

34. Stevens, N. E. 1916. A method for studying the humidity relations of fungi in culture. Phytopathology 6:428-432.

35. Sutton, T. B., and Jones, A. L. 1979. Analysis of factors affecting dispersal of Podosphaera leucotricha conidia. Phytopathology 69:380383.

36. Thomas, C. S., Gubler, W. D., Leavitt, G. 1994. Field testing of a powdery mildew disease forecast model on grapes in California (Abstr.) Phytopathology 84:1070.

37. Turner, D. M. 1956. Studies on cereal mildew in Britain. Trans. Br. Mycol. Soc. 39:495-506.

38. Unwin, D. M. 1980. Microclimate measurements for ecologists. Academic Press, London.

39. Weber, E., Gubler, D., and Derr, A. 1996 Powdery mildew controlled with fewer fungicide applications. Practical Wine \& Vineyard, Jan./Feb., pp. 2-4.

40. Weinhold, A. R. 1961. Temperature and moisture requirements for germination of conidia of Sphaerotheca pannosa from peach. Phytopathology 51:699-703.

41. Yarwood, C. E. 1936. The diurnal cycle of the powdery mildew Erysiphe polygoni. J. Agric. Res. 52:645-657.

42. Yarwood, C. E. 1957. Powdery mildews. Bot. Rev. 23:235-301 